\title{
UNCLASSIFIED
}

NRL Report 4263

NYO-3788

\section{A STUDY OF PREFERRED ORIENTATION IN ROLLED URANIUM BARS BY MEANS OF SONIC AND ULTRASONIC VIBRATIONS}

S. D. Hart, E. W. Kammer and I. Vigness

Mechanics Division

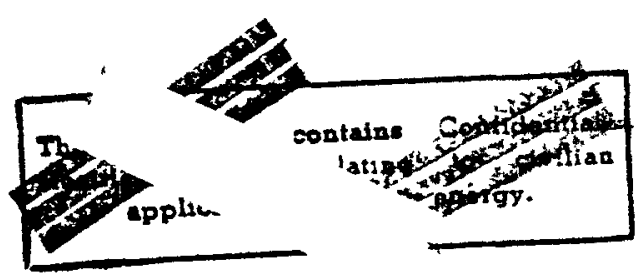

October 15, 1953

This document is PUBLICLY RELEASABLE ORO Review Team Authorizing Official Date $11-9-2010$
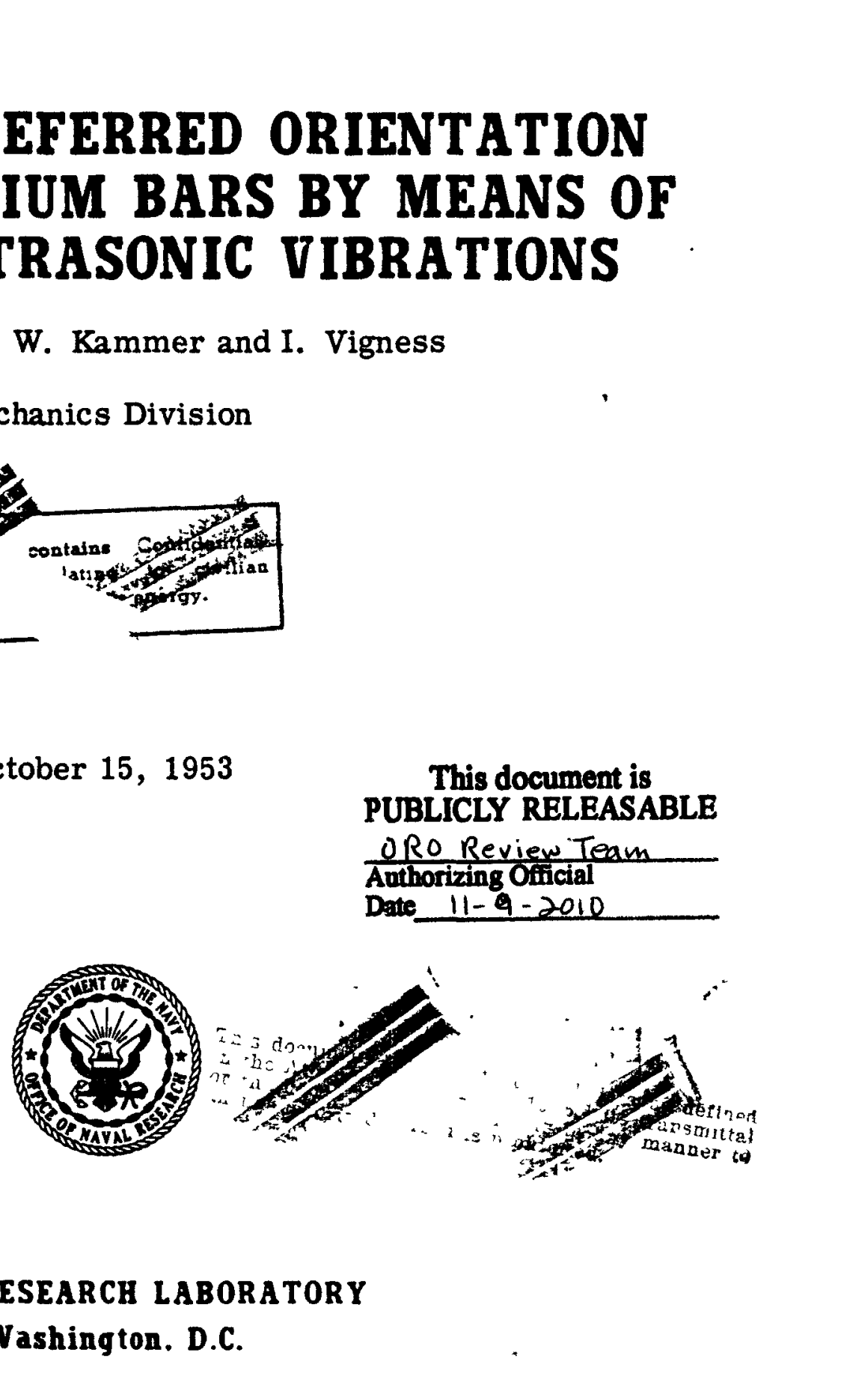

NAVAL RESEARCH LABORATORY Washington. D.C.

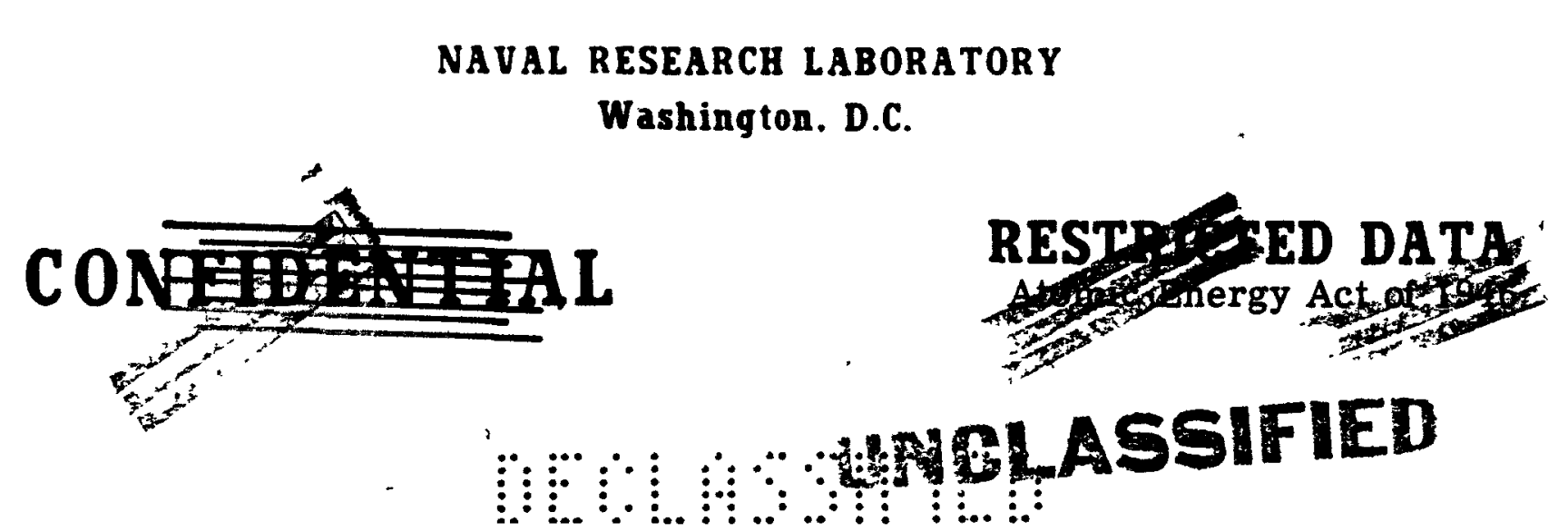




\title{
A STUDY OF PREFERRED ORIENTATION IN ROLLED URANIUM BARS BY MEANS OF SONIC AND ULTRASONIC VIBRATIONS
}

\author{
S. D. Hart, E. W. Kammer and I. Vigness
}

\section{LEGAL NOTICE}

This report was prepared as an account of Government sponsored work. Neither the United States, nor the Commission. nor any person acting on behalf of the Commission:

A. Makes any warranty or representation, express or implied, with respect to the accuracy, completeness, or usefulness of the information antainid in this report, or that the use of any information, apparatus, method, or process disclosed in this report may not infringe privately owned rights; or

B. Assumes any liabilities with respect to the use of, or for damages resulting from the use of any information, apparatus, method, or process disclosed in this report.

As used in the above, "person acting on behalf of the Commission" includes any employee or contractor of the Commission to the extent that such employee or controctor prepares, handles or distributes, or provides access to, any information pursuant to his employment or contract with the Commission.

Work Performed undęr Contract No. AT(30-1)-1344 Atomic Energy Commission - New York Operations Office

\section{NAVAL RESEARCH LABORATORY}

Washington. D.C. 
2 


\section{DISCLAIMER}

This report was prepared as an account of work sponsored by an agency of the United States Government. Neither the United States Government nor any agency Thereof, nor any of their employees, makes any warranty, express or implied, or assumes any legal liability or responsibility for the accuracy, completeness, or usefulness of any information, apparatus, product, or process disclosed, or represents that its use would not infringe privately owned rights. Reference herein to any specific commercial product, process, or service by trade name, trademark, manufacturer, or otherwise does not necessarily constitute or imply its endorsement, recommendation, or favoring by the United States Government or any agency thereof. The views and opinions of authors expressed herein do not necessarily state or reflect those of the United States Government or any agency thereof. 


\section{DISCLAIMER}

Portions of this document may be illegible in electronic image products. Images are produced from the best available original document. 


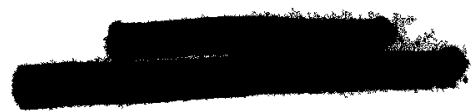

Introduction

The infial objective for this project was the location of flaws in rolled uranium bars by means of sonic and ultrasonic techniques. However, the commonly encountered defects proved to be of such small size or unfavorable orientation that the avallable inspection methods could not satisfactorily evaluate the degree, of inhomogeneity present in the specimens initially submitted ${ }^{1}$.

The requirement that specimens be in nearly the final form of manufacture for reactor applications created severe handicaps. The bars could not be sectioned or cut up in any way. Hence a detalled study of preferred orientation patterns in any cross section could not be made. It was possible, nevertheless, to measure ultrasonic velocity for compressional waves both along the bar axis and the diameters with sufficlent accuracy to demonstrate that a high degree of elastic anisotropy existed ${ }^{1}$. This also became evident from the flexural modes of vibration at sonic frequencies. Since anisotropy could be undesirable, particularly from the standpoint of dimensional stability when the material experiences large temperature changes, further tests have been made on specimens having known metallurgical histories.

Results

A description of the specimens used for this study is contained in Table 1 . The ultrasonic velocity data are contained in Table 2. Figures 1, 3, 5, 7, and 9 display the variation in ultrasonic velocity along various diameters for Group A specimens. The corresponding plot of the flexural mode vibration is given in Figures $2,4,6,8$, and 10. These specimens probably represent typical cases of anisotropy that rolled uranium acquires without further heat treatment. Their metallurgical history was not available for inclusion in this report. Figures $11-15$ contain the azimuthal patterns of flexural vibration amplitudes for various planes about the rod axis for each specimen of Group B'。

A detalled examination of bar number $A B C-1-13$ of Group $B$ was made to point out that the flexural mode amplitude pattern is independent of both the variations in diameter and the deviation of the rod from a straight cylinder. Bar ABC1-13 was an extreme example of those which were warped by the

I Progress Report for March 1952 through August 1952, NYO-3787 


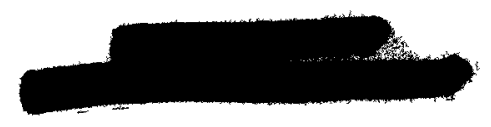

heat treatment. The plane of the bend is indicated on Figure 15 while the diametral variations are plotted with the vibration amplitudes on Figure 16.

Discussion

The ultrasonic measurements show that a marked reduction in elastic anisotropy has been accomplished by the beta treatment. Alpha bars exhibit velocities along the axis as much as 8\% less than that along their diameters. The beta treated bars display nearly the same velocity along all diameters and the axis, about 134,000 inches per second. This velocity is between the extreme values measured in the alpha bars. It is of interest to point out here without explanation that the velocities measured in an unworked cast specimen, a so-called "egg" portion of an ingot, yielded the high value of 139,700 in/sec along two directions through the specimen at right angles with each other.

Another qualitative indication of improvement towards homogeneity is evidenced by the oscillograms in Figures 17 and 18. For the alpha material, Figure 17, the transmitted pulse has been modifled while passing through the bar parallel to the axis, so that the first arrival is smaller in amplitude than the immediately following delayed wave train, or subsidiary. In the beta treated material, Figure 18, for the same transmission path length and bar diameter, the character of the arrival pulses differs greatly, the first arrival having greater amplitude than the following subsidiary. A similar phenomenon takes place in a homogeneous material, when the rod length is increased. Energy is drained from the leading pulse and transferred to the subsidiary pulses until a state is attained in which the first subsidiary is stronger than the leading pulse. With sufficiently long travel time this process can reach a stage for which the initial pulse has been completely cannibalized and subsidiaries only are detectable. Although the geometrical conditions for Figures 17 and 18 are 1dentical, the subsidiary generating process has been markedly accelerated in the alpha uranium, implying that the elastic inhomogene1ty has had a strong effect upon the transmission. A detalled explanation of the interaction between the Inhomogeneity pattern and the ultrasonic waves is not available at this time.

The specially heat treated specimens in Group C still contalned considerable anisotropy. However, the spread between axial and diametral velocities was narrower than that found in Group A. There seemed to be a slight dependence of the 
axial velocity upon the rolling temperature, the highest temperature corresponding with the highest velocity. There was also less variation in the diametral velocity for a given bar, so little in fact, that no azimuthal velocity patterns were obtained. However, there still remained diameters exhibiting optimum transmission.

It is concluded therefore, that for the fabrication sequences studied here, those which include a final heat treatment above the alpha-beta temperature are the most effective in minimizing the preferred orientation induced by roliing. 


\section{Table 1}

Description of Specimens

Bar No. $\quad \begin{array}{ll}\text { Diameter } & \text { Length } \\ \text { (inches) } & \text { (inches) Remarks }\end{array}$

Group A

$\begin{array}{llll}2779-3-16 & 0.9971 \pm .0005 & 8.05 & \begin{array}{l}\text { There are no } \\ \text { metallurgical data }\end{array} \\ 2889-4-6 & 0.9874 \pm .0002 & 8.06 & \begin{array}{l}\text { avallable on the } \\ \text { specimens In Group }\end{array} \\ 3018-2-20 & 0.9964 \pm .0001 & 8.05 & \mathrm{~A} . \\ 3077-\mathrm{F}-18 & 0.9871 \pm .0002 & 8.06 & \\ 3077-\mathrm{F}-21 & 0.9877 \pm .0001 & 8.06\end{array}$

Group B

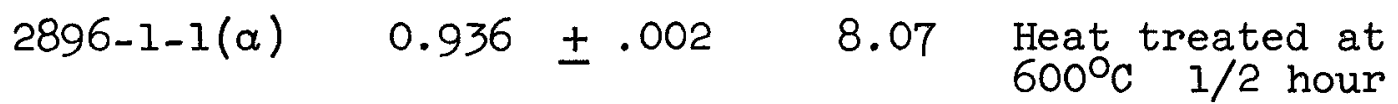

$2892-4-1(\alpha) \quad 0.993 \pm .001 \quad 8.09$ Heat treated at $600^{\circ} \mathrm{C} 1 / 2$ hour

$A B C-1-13(\beta) \quad 0.9904 \pm .0003 \quad 8.06$ Heat treated at $720^{\circ} \mathrm{C} 70$ seconds.

$\begin{array}{llll}2896-2-27(\beta) & 0.9940 \pm .0003 & 8.06 \quad \begin{array}{l}\text { Heat treated at } \\ 720^{\circ} \mathrm{C} \quad 70 \text { seconds. }\end{array}\end{array}$

$\begin{array}{llll}6339-\mathrm{B}-22(\beta) & 0.988 \pm .001 & 8.05 \quad \begin{array}{l}\text { Heat treated at } \\ 720^{\circ} \mathrm{C} \quad 70 \text { seconds }\end{array}\end{array}$

Group C (12 bars, 4 in each temperature class)

\begin{tabular}{|c|c|c|c|}
\hline $\begin{array}{l}4 \mathrm{D} 621-\mathrm{A} \\
630^{\circ} \mathrm{C}\end{array}$ & $0.9270 \pm .0002$ & 8.00 & $\begin{array}{l}\text { Rough rolled to } \\
1-1 / 2^{\prime \prime} \text { dia.at } 600^{\circ} \mathrm{C} \text {. } \\
\text { Finish rolled at } \\
630^{\circ} \mathrm{C} \text { to } 1^{\prime \prime} \text { dia. } \\
\text { then ground. }\end{array}$ \\
\hline $\begin{array}{r}4 \mathrm{D} 6211^{\circ} \mathrm{C} \\
550^{\circ} \mathrm{C}\end{array}$ & $0.9270 \pm .0002$ & 8.00 & $\begin{array}{l}\text { Finish rolled at } 550^{\circ} \mathrm{C} \\
\text { to } 1^{\prime \prime} \text { dia. then ground }\end{array}$ \\
\hline $\begin{array}{r}4 D 6211^{-C} \\
480^{\circ} \mathrm{C}\end{array}$ & $0.9270 \pm .0002$ & 8.00 & $\begin{array}{l}\text { Finish rolled at } 480^{\circ} \mathrm{C} \\
\text { to } 1^{\prime \prime} \text { dia. then ground. }\end{array}$ \\
\hline
\end{tabular}


$\underline{T a b l e} \underline{2}$

Longitudinal Velocity Measurements

at Room Temperature

\begin{tabular}{llll} 
Bar No. & $\begin{array}{l}\text { Velocity } \\
\text { Along the } \\
\text { Axis } \\
(103 \text { 1n/sec) }\end{array}$ & $\begin{array}{l}\text { Velocity } \\
\text { Along Dia- } \\
\text { meters } \\
(103 \text { in/sec) }\end{array}$ & Remarks \\
\hline Group A & & & \\
$2779-3-16$ & 128.0 & $135.3-138.3$ & $\begin{array}{l}\text { Pronounced preferred } \\
\text { orientation. }\end{array}$ \\
$3889-4-6$ & 128.1 & $136.5-138.5$ & \\
$3018-2-20$ & 128.0 & $135.2-138.7$ & \\
$3077-$ F-18 & 129.0 & $135.1-138.9$ & \\
$3077-$ F-21 & 128.9 & $135.7-139.2$
\end{tabular}

Group B

$\begin{array}{llll}2896-1-1(\alpha) & 129.2 & 136.0-137.0 & \begin{array}{l}\text { SIight variation in } \\ \text { transmission along } \\ \text { various dia.normal } \\ \text { to cylindrical axis. }\end{array} \\ \text { ABC-1-13(B) } & 132.0 & 133.6 & \begin{array}{l}\text { Two slight1y preferred } \\ \text { dia. of transmission. }\end{array} \\ 2896-2-27(\beta) & 132.1 & 132.5 & \begin{array}{l}\text { No preferred dia- } \\ \text { meters. }\end{array} \\ 6339-B-22(B) & 135.4 & 133.5 & \end{array}$

Group $\underline{\mathrm{C}}$

\begin{tabular}{crll}
$\begin{array}{c}4 \mathrm{D} 621 \\
630^{-}\end{array}$ & 130.9 & $134.5-135.0$ & $\begin{array}{l}\text { Slight variation } \\
\text { along various dia. } \\
550^{\circ}\end{array}$ \\
129.7 & $134.5-135.3$ & $\begin{array}{l}\text { normal to cylindrical } \\
\text { axis. }\end{array}$ \\
$480^{\circ}$ & 128.6 & $135.2-135.9$ & \\
\hline Cast "Egg" & 139.7 & 139.8 & $\begin{array}{l}\text { Tested along 2 direc- } \\
\text { tions at right angles. }\end{array}$
\end{tabular}


BAR No. $2770-3-16$

AXIAL VELOCHTY $-123000(\mathrm{in} / \mathrm{sec})$

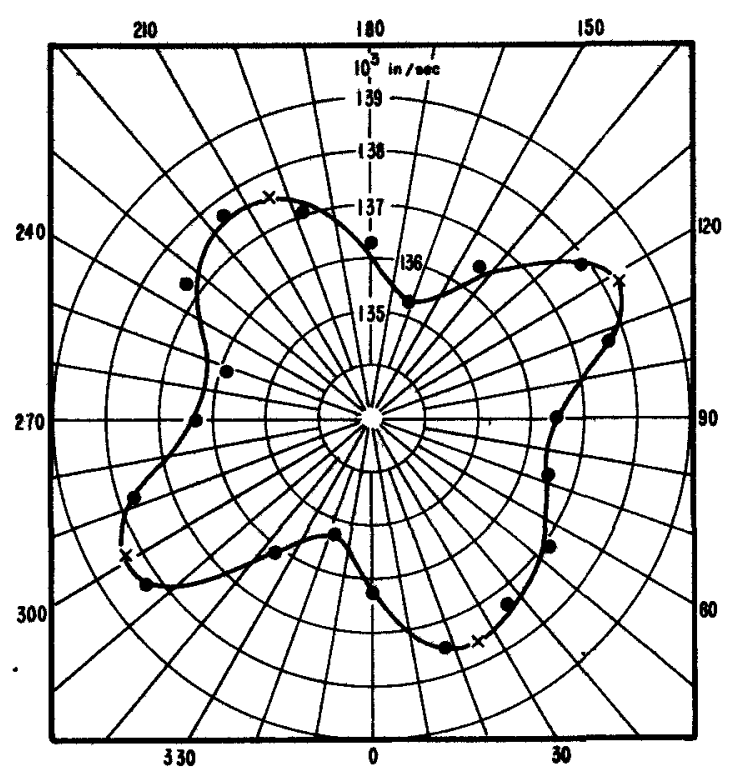

FI GURE 1
BAR 40. 2889-4-6

AXIAL VELDCITH-1a $1900(\mathrm{~m} / \mathrm{mec})$

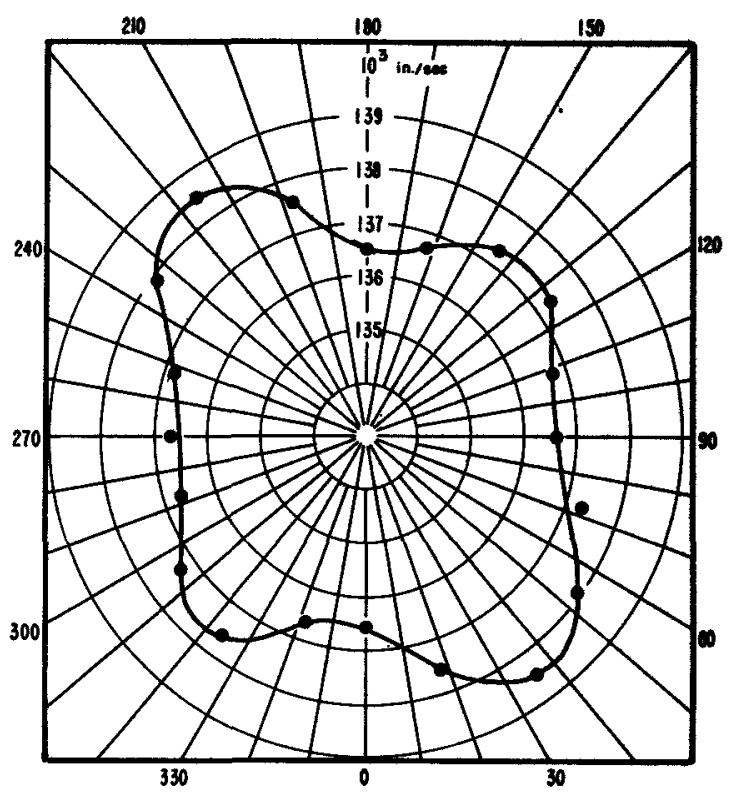

FI GURE 3

PULSE VELOCITY FOR VARIOUS DIRECTIONS OF TRANSMISSION NORMAL TO THE BAR AXIS.

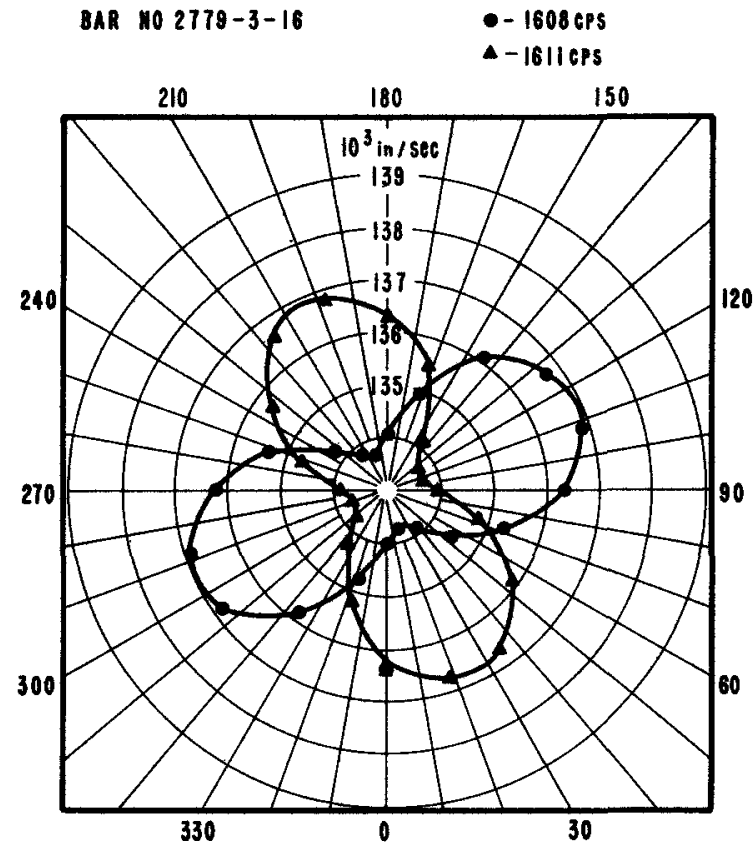

FI GURE 2

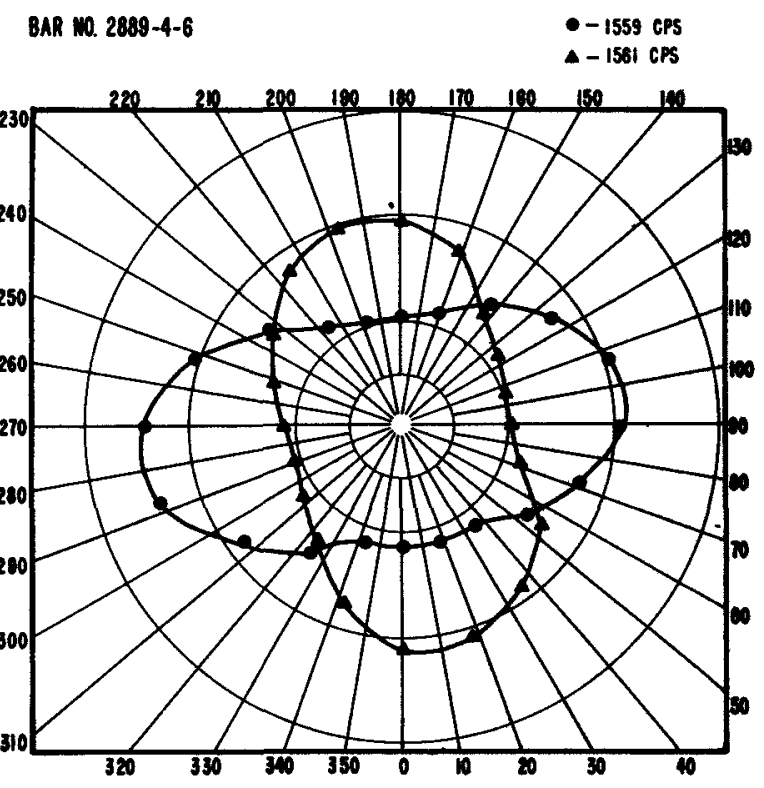

FI GURE 4

Polar plot of the first flexural mode vibation amplitude..

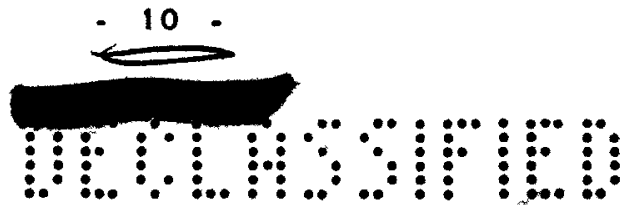


Bur n. 3018-2-20

AXIAL VELDEITT-120000 (in/sec)

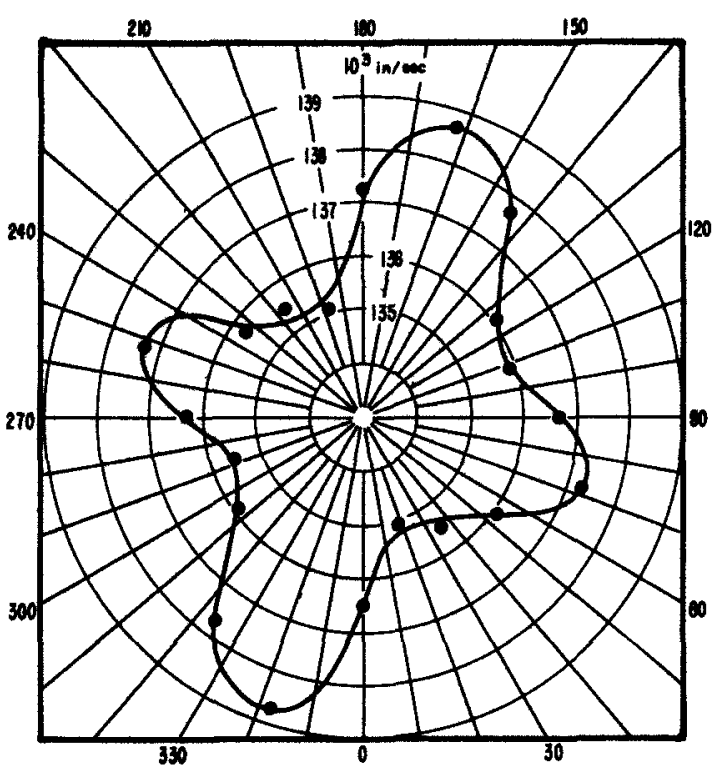

FI GURE 5

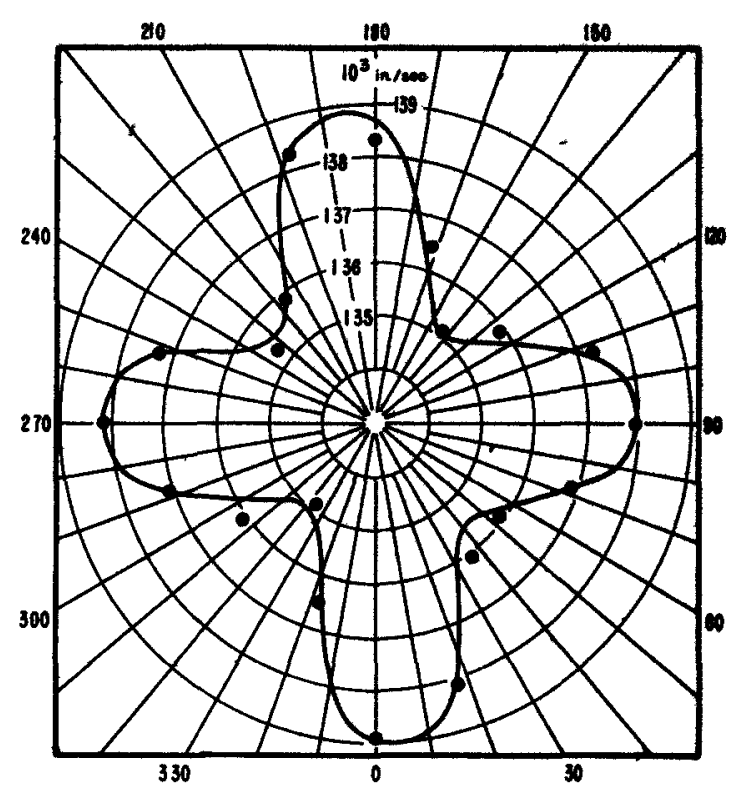

FI GURE 7

PULSE VELOCITY FOR VARIOUS DIRECTIONS OF TRANSMISSION NORMAL TO THE BAR AXIS.

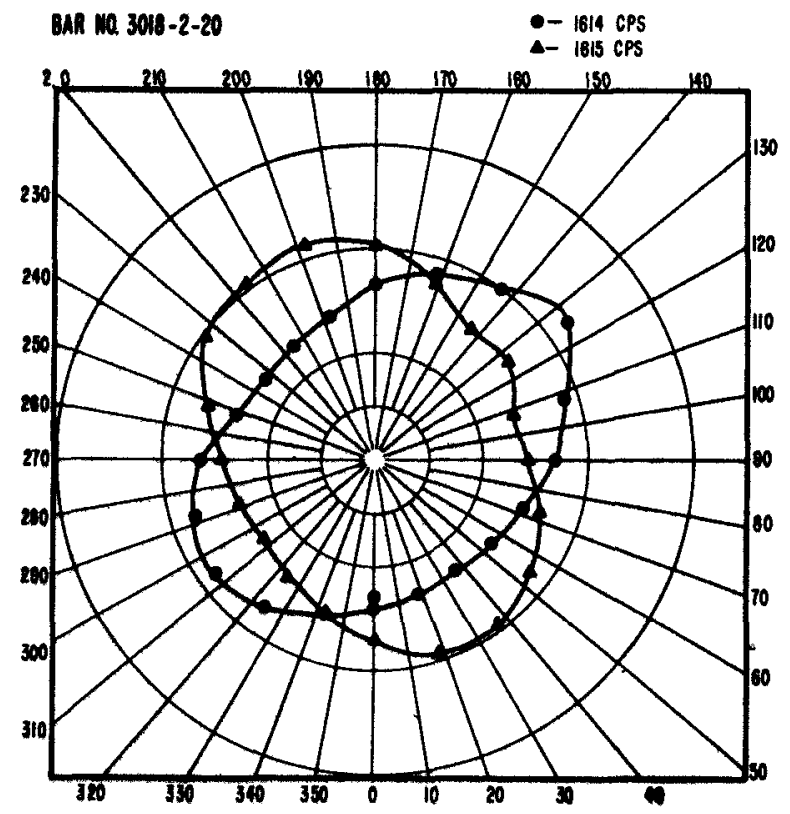

FI GURE 6

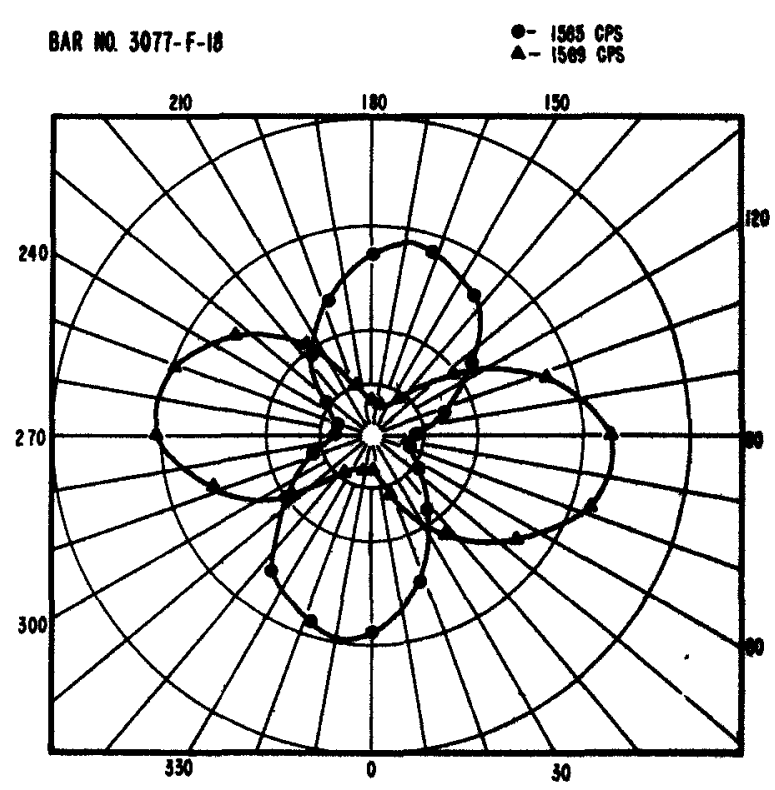

FIGURE 8

PQlar plot of the first flexuRal MOde ViBRation amplitude. 


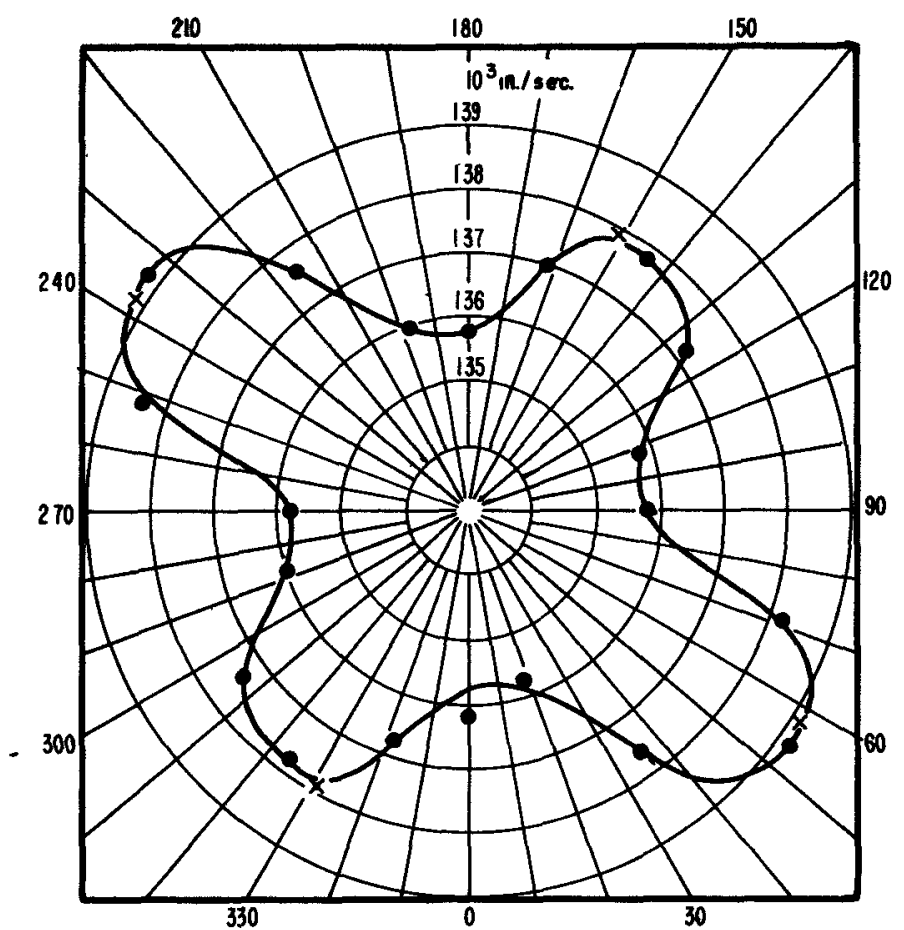

FI GURE 9

PULSE VELOCITY FOR VARIOUS DIRECTIONS OF TRANSMISSION
NORMAL TO THE BAR AXIS.

BAR NO. 3077-F-21

$$
0-15653
$$

$\Delta-15695$

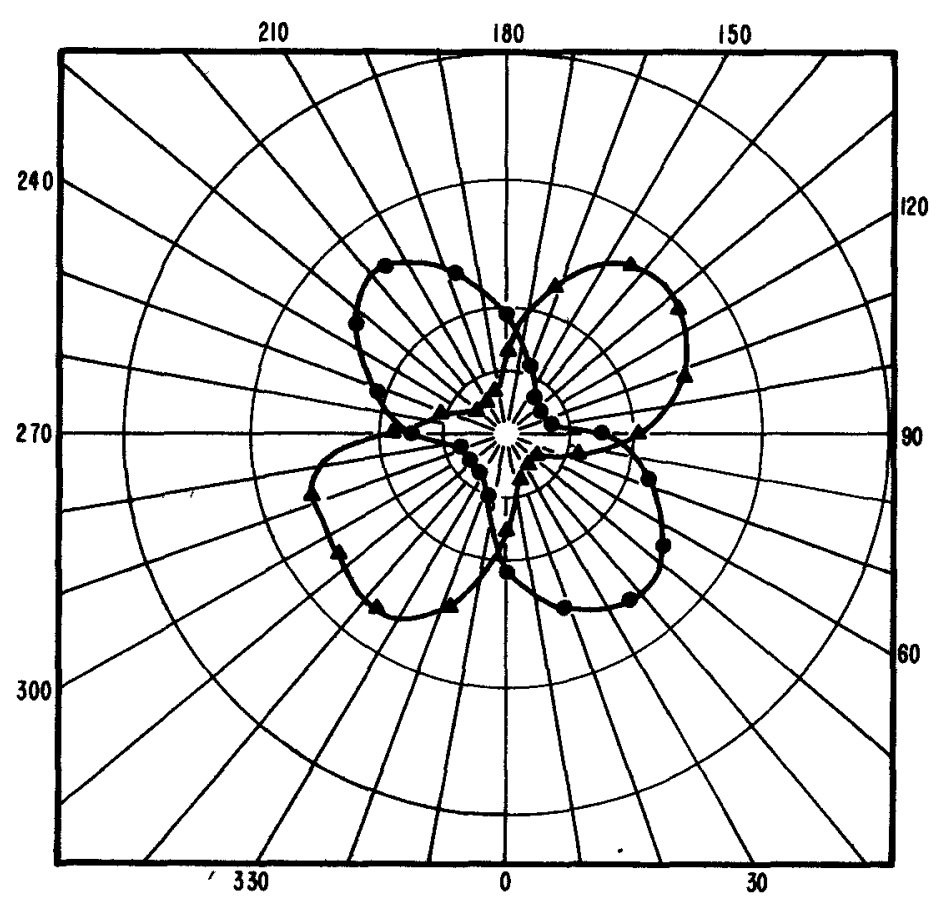




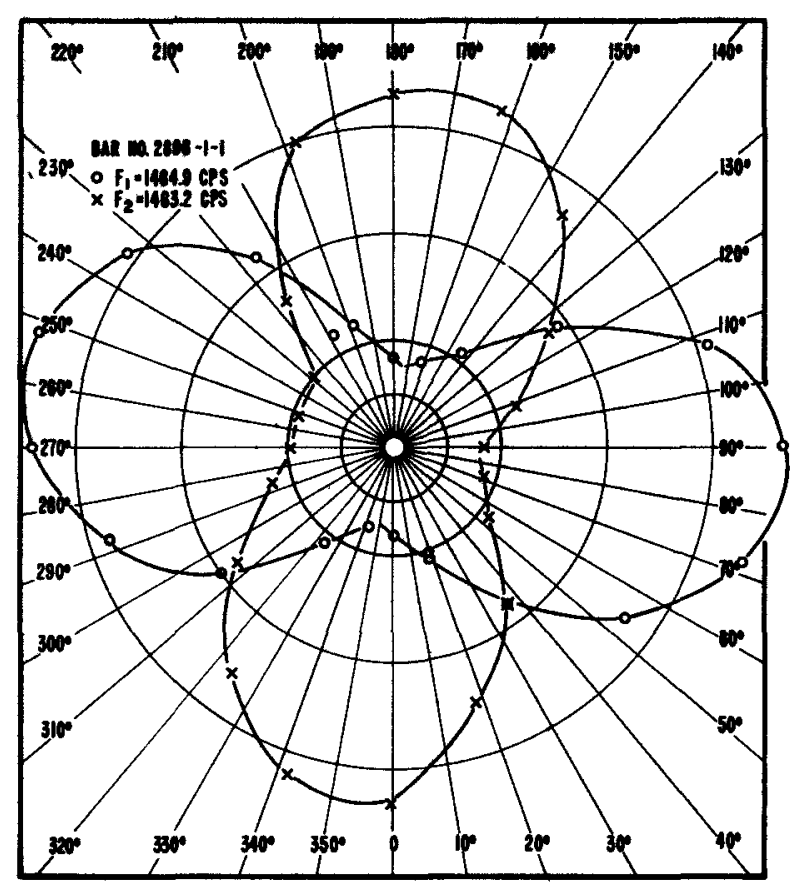

FIGURE II

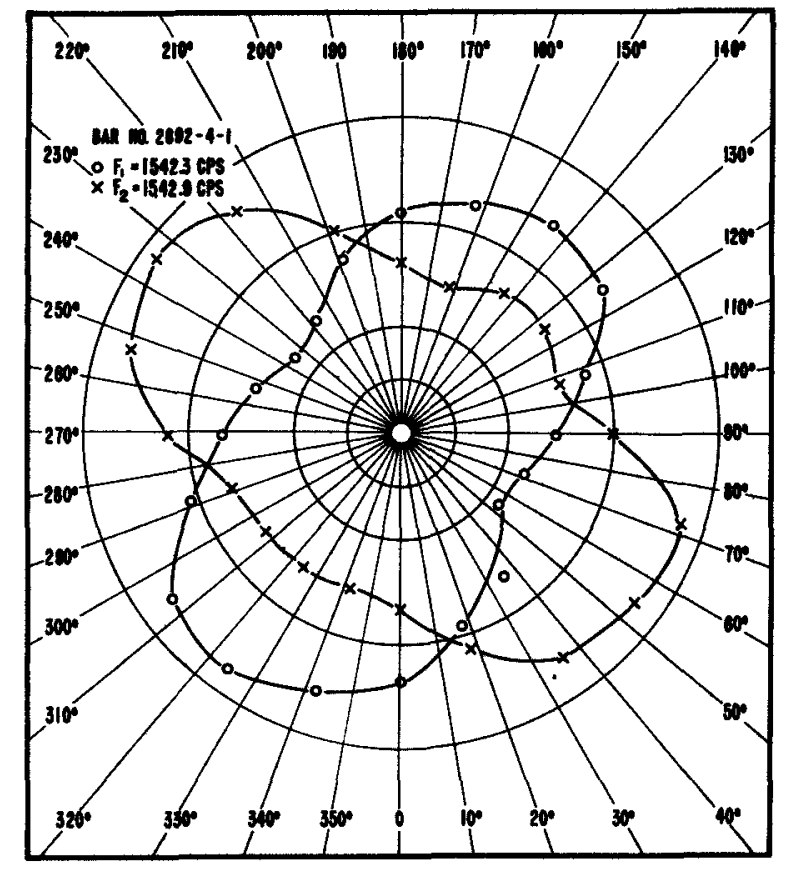

FIGURE 12

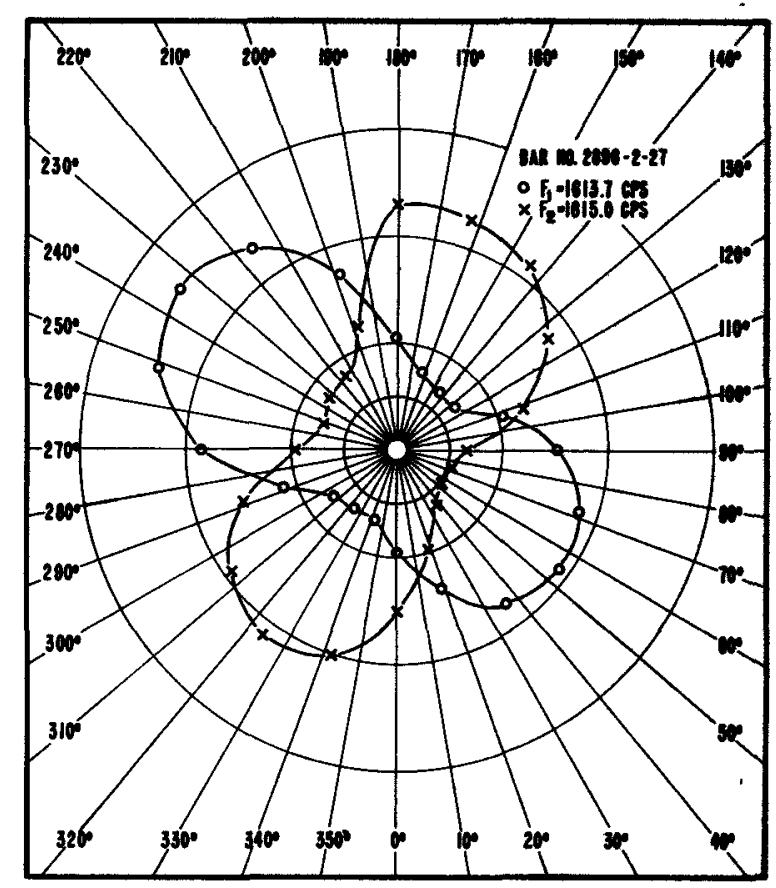

FI GURE 13

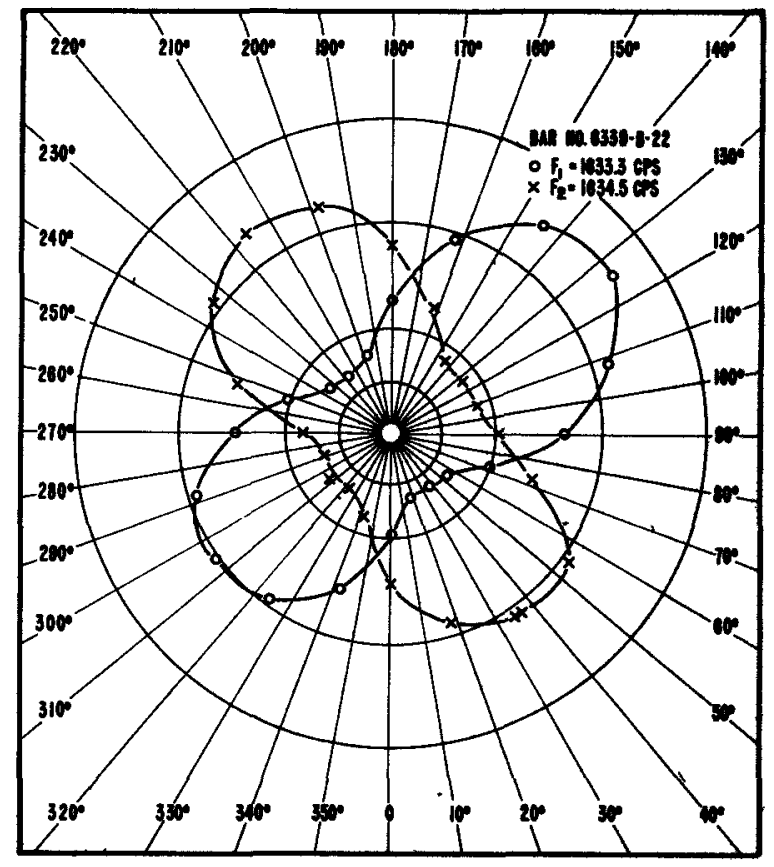

FI GURE 14

Polar plot of the first flexural mode Vibration amplitude. 


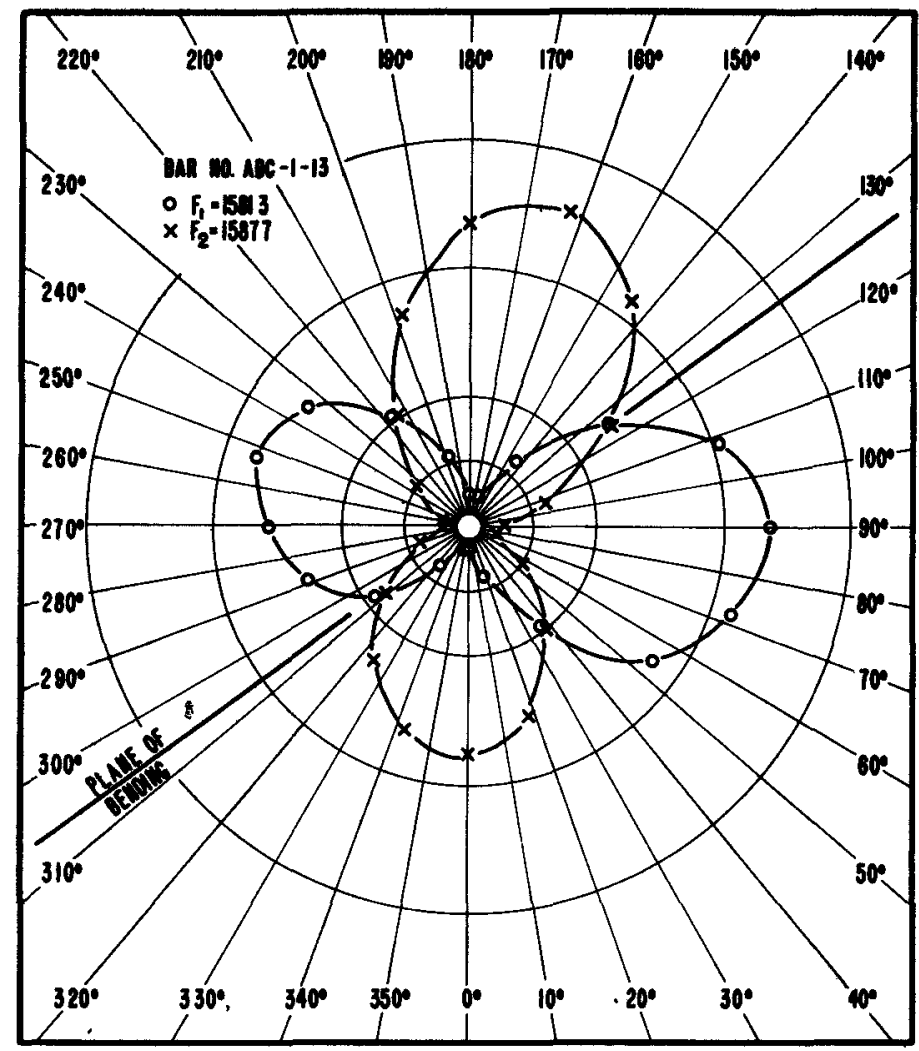

figure 15 Polar plot of the first flexural mode vibration amplitude.

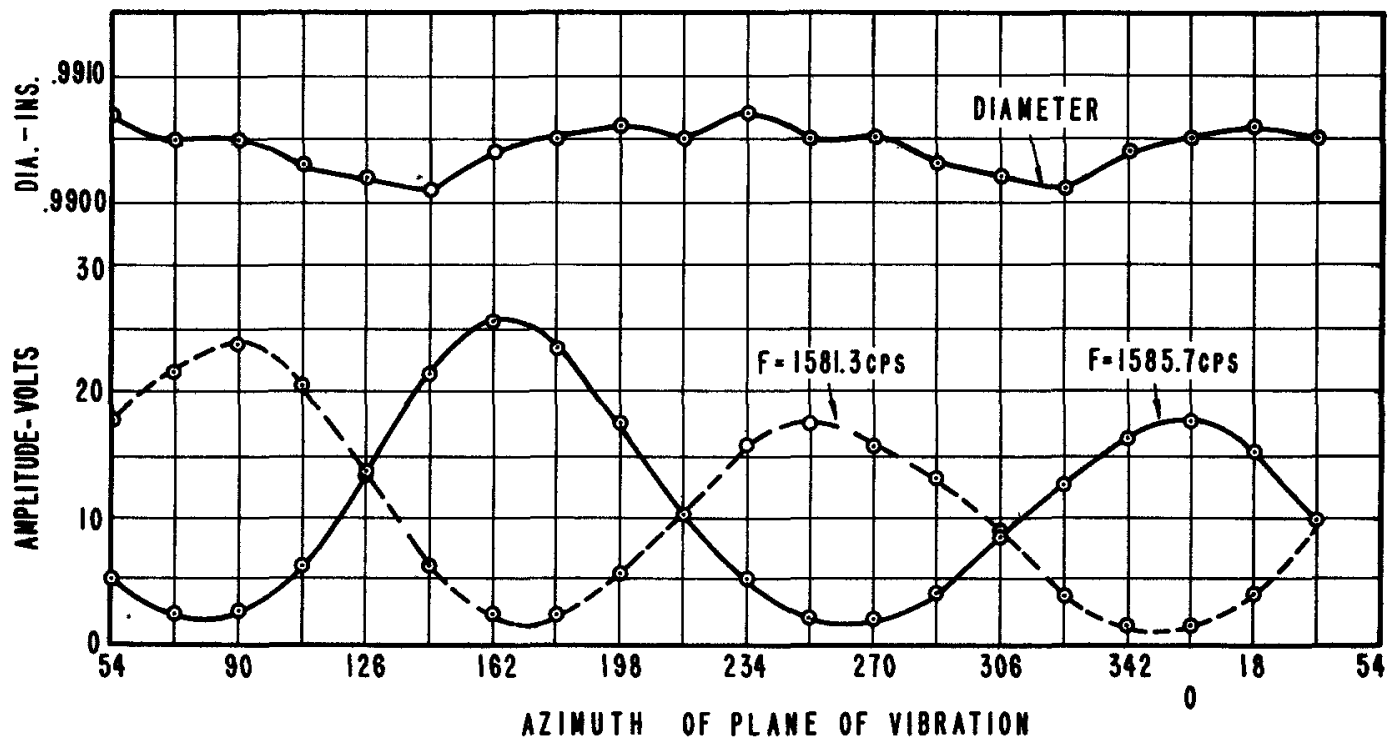

FI GURE 16 A COMPARISON OF THE FIRST FLEXURAL MODE VIBRATION AMPLITUDE WITH THE BAR DIAMETER IN THE PLANE OF VI BRATION. 


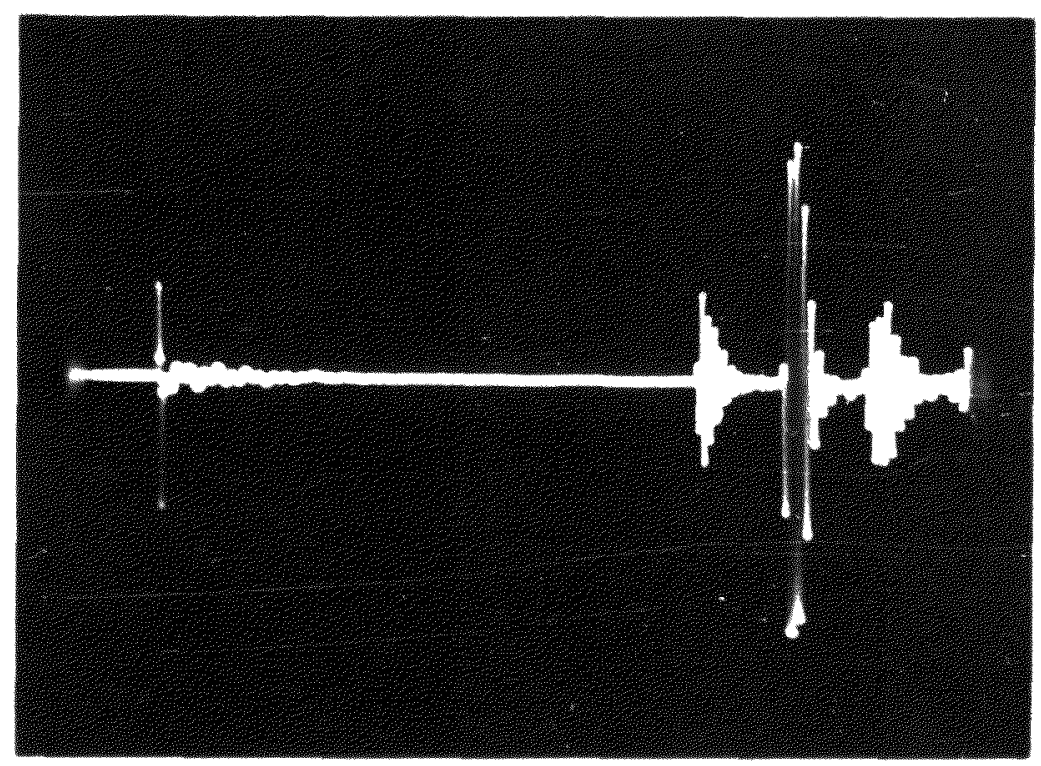

FIGURE 17 LONGITUDINAL PULSE TRANSMISSION ALONG AXIS OFOBAR FOR $1 / 2$ HOUR.

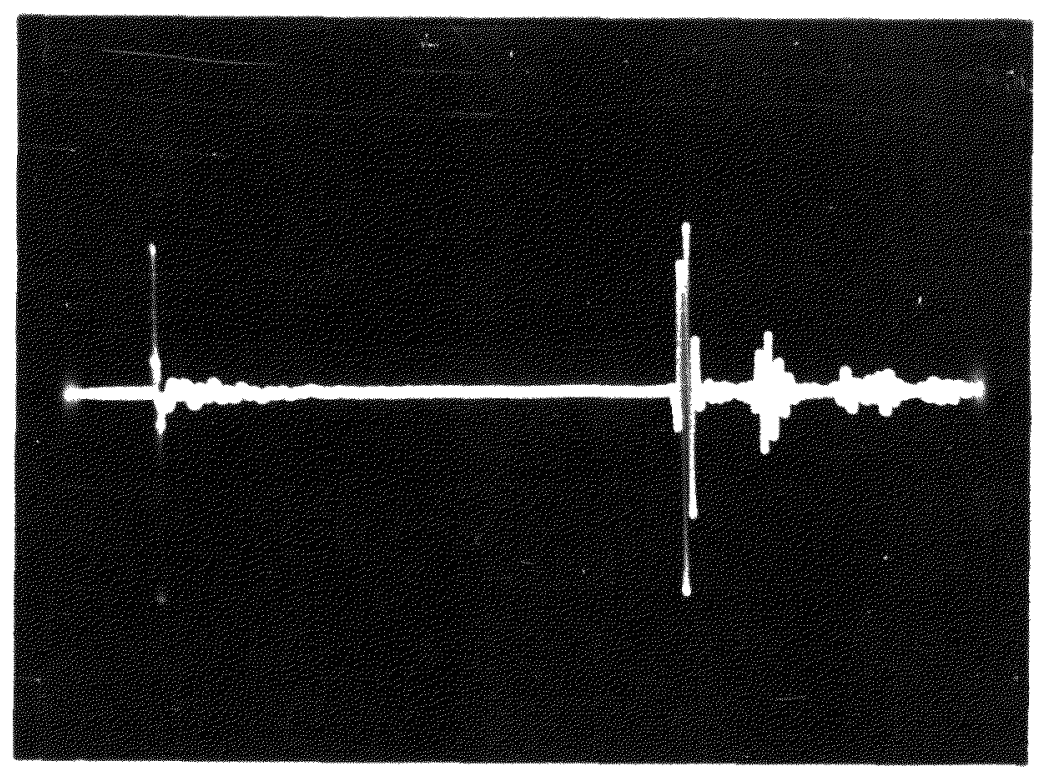

FIGURE 18 LONGITUDINAL PULSE TRANSMISSION ALONG AXISSOFBAR $7200^{\circ} \mathrm{C} 39 \mathrm{FB}^{3} 70^{2}$ SE A BETA TREATED SPECIMEN ANNEALED AT

\section{5.}
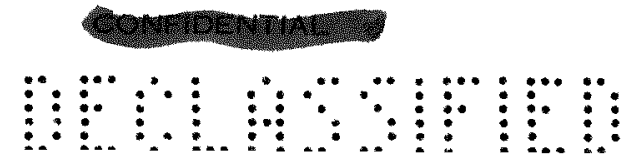